\title{
Proteinase-activated receptors (PARs) as targets for antiplatelet therapy
}

Authors: Margaret Cunningham, Kathryn Mclntosh, Trevor Bushell, Graeme Sloan, \& Robin Plevin

Address: Strathclyde Institute of Pharmacy and Biomedical Sciences (SIPBS), University of Strathclyde, 161 Cathedral Street, Glasgow, G4 ORE.

Correspondence: Dr Margaret Rose Cunningham, Strathclyde Institute of Pharmacy and Biomedical Sciences (SIPBS), University of Strathclyde, 161 Cathedral Street, Glasgow, G4 ORE. Email: margaret.cunningham@strath.ac.uk. Tel: +44 1415484954.

Keywords: GPCRs / PARs / Thrombosis / Modulators

\author{
Abbreviations used \\ Proteinase-activated receptors (PARs), G protein-coupled receptors (GPCRs), Extracellular loop 2 (ECL2), \\ Intracellular loops (ICLs)
}

\begin{abstract}
Since the identification of the proteinase-activated receptor (PAR) family as mediators of serine protease activity in the 1990's, there has been tremendous progress in the elucidation of their pathophysiological roles. The development of drugs that target PARs has been the focus of many laboratories for the potential treatment of thrombosis, cancer and other inflammatory diseases. Understanding the mechanisms of PAR activation and G protein signaling pathways evoked in response to the growing list of endogenous proteases has yielded great insight into receptor regulation at the molecular level. This has led to the development of new selective modulators of PAR activity, particularly PAR1. The mixed success of targeting PARs has been best exemplified in the context of inhibiting PAR1 as a new antiplatelet therapy. The development of the competitive PAR1 antagonist, vorapaxar (Zontivity), has clearly shown the value in targeting PAR1 in acute coronary syndrome (ACS); however the severity of associated bleeding with this drug has limited its use in the clinic. Due to the efficacy of thrombin acting via PAR1, strategies to selectively inhibit specific PAR1-mediated G protein signaling pathways or to target the second thrombin platelet receptor, PAR4, are being devised. The rationale behind these alternative approaches is to bias downstream thrombin activity via PARs to allow for inhibition of pro-thrombotic pathways but maintain other pathways that may preserve hemostatic balance and improve bleeding profiles for widespread clinical use. This review summarizes the structural determinants that regulate PARs and the modulators of PAR activity developed to date.
\end{abstract}




\section{Introduction}

Proteinase-activated receptors (PARs) are a family of G protein-coupled receptors (GPCR) that promote cellular activity in response to serine proteases in the body [1]. Four family members (PAR1-4) have been cloned [2-5]; the roles of which are as varied as the serine proteases that activate them. Early studies delineating the process of PAR activation describe thrombin as the predominant protease for PAR1, PAR3 and PAR4, whilst trypsin-related proteases preferentially target PAR2, and to a lesser extent, PAR4 [1]. Whilst these canonical proteases have been researched in great detail, a substantial number of non-canonical proteases that activate PARs have emerged and are in the early stages of investigation [6]. This review will primarily focus on the canonical activation of PARs by thrombin.

\section{Mechanisms of PAR cleavage and activation}

The protease-substrate recognition process is highly coordinated. Serine proteases, such as thrombin, typically target substrates through the ability to recognize distinct amino acid residues, with preference for an arginine or lysine at position P1 and proline at P2 of the substrate cleavage site [7]. Evidence suggests that thrombin binding and cleavage of PARs involves the formation of a 3-dimensional structure between leucine residues in PAR1 (position P4) and PAR4 (position P5) and a putative proline residue in P2 of the cleavage site on the PAR N-terminus (Figure 1). This aids recognition by thrombin to support receptor cleavage [8]. Thrombin binding is also facilitated by the presence of a 'hirudin-like' domain distal to the cleavage site of PAR1 ( $D^{50}$ KYEPFWEDEE) and PAR3 ( ${ }^{48}$ EEFP), which binds to the exosite I of thrombin [9]. PAR4 lacks a hirudin-like thrombin binding domain [4] and requires higher concentrations of thrombin (5 nM) to elicit comparable half-maximal signaling responses (phosphatidylinositol hydrolysis) induced by thrombin via PAR1 (0.2 nM). Thrombin-mediated cleavage of PAR4 is enhanced however through cooperation with PAR1 and PAR3. Both of these receptors serve as cofactors for thrombin to cleave and activate PAR4 [10, 11]. Through the ability of PAR1 and PAR3 to bind to exosite I of thrombin, the active site within thrombin is then free for cleavage of adjacent substrates, such as PAR4. This was first demonstrated using X-ray crystal structures of murine thrombin in complex with murine PAR3 and PAR4 extracellular regions [12]. Another study by Nieman and colleagues further delineated this mechanism in relation to PAR1- assisted cleavage of PAR4 by thrombin [11]. This study found that PAR1/PAR4 heterodimer formation is essential for PAR1assisted cleavage of PAR4. The functional relevance of PAR cofactoring has recently been the topic of a comprehensive review by Trejo and colleagues [13]. The ability of PAR3 to cofactor PAR4 is essential for efficient murine platelet activation [10].

Following recognition, thrombin binds transiently to PAR1, PAR3 and PAR4 and irreversibly cleaves these receptors at the $\mathrm{N}$-terminus prior to dissociation [14]. Proteolytic cleavage of the extracellular $\mathrm{N}$-terminus results in the exposure of a unique tethered ligand. This tethered domain engages superficially with residues that comprise the extracellular loop 2 (ECL2) to promote self-activation and trigger signal transduction [15]. Once proteolytic activation has taken place, PARs are terminally downregulated and require synthesis of fresh receptor to maintain responsiveness to extracellular proteases [16].

Synthetic peptides that mimic the tethered ligand domain for each PAR have been developed over the years [17]. These peptides bypass the cleavage process and bind directly to ECL2 regions to promote receptor activation. Studies using synthetic PAR-selective peptide agonists and PAR knock out mice models have been valuable in elucidating the importance of PAR subtype activity in particular disease processes. Well established roles for PARs include platelet activation that precedes thrombosis [18], cancer invasion and metastasis [19] and activation of pivotal pathways that promote acute and chronic inflammation (e.g. arthritis) [20]. 


\section{PAR cleavage and non-PAR related activity}

PAR-independent effects have been reported for the 41 amino acid cleaved peptide derived from PAR1 [21]. This liberated region of PAR1 is referred to in the literature as parstatin (Figure 1). Upon proteolytic unmasking of the PAR1 tethered ligand domain, parstatin is cleaved from the receptor and can act as a cell penetrable peptide to evoke pathways that modulate angiogenesis and renal ischemia in vitro [21, 22]. The functional capabilities of parstatin add to the diverse cellular activity possible upon proteolytic cleavage of PAR1. Whether the cleaved peptide derived from other PAR family members display any efficacy remains to be determined. Investigations into the protective role of parstatin in vivo are ongoing [23].

\section{PAR Signaling}

The activation of PARs results in the stimulation of numerous intracellular signaling cascades. Classical heterotrimeric guanine nucleotide-binding protein (G protein) dependent pathways downstream of PAR activation have been well characterized for each PAR subtype [24]. PAR1 and PAR2 functionally couple to multiple $\mathrm{G}$ proteins including the $\mathrm{G} \alpha \mathrm{q} / 11$, Gai/o, and $\mathrm{G} \alpha 12 / 13$ subfamilies [25-27]. Despite cleavage by thrombin, PAR3 does not signal conventionally via G proteins like the other PARs [10]. PAR3 can however enhance PAR1-Ga13 coupling through its ability to form a heterodimer with PAR1 [28]. There have been reports of IL-8 and ATP release downstream of thrombin-mediated PAR3 activation however direct coupling with specific $\mathrm{G}$ proteins remains unclear $[29,30]$. Activation of PAR4 is reported to promote $\mathrm{G} \alpha \mathrm{q} / 11$ and $\mathrm{G} \alpha 12 / 13$ mediated cellular responses [31, 32]. In addition to coupling to $\mathrm{G}$ proteins, PARs are known to signal via interaction with adapter proteins such as beta-arrestin 1 and 2 [33] and transactivation of receptor kinases such as EGFR [34].

\section{PAR Signaling - Ligand bias}

The signaling events that occur upon PAR activation will depend upon the protease involved, the cell type in which the PAR is expressed and the pathological context in question. Signaling bias downstream of PAR activation has become a hot topic in recent years following the identification of new proteases capable of cleaving PARs $[6,35]$. Indeed, the repertoire of proteases capable of regulating PAR activity is increasing rapidly (Table 1$)$. For example, activated protein-C (APC) can cleave PAR1 $\left(R^{46}\right)$ at a different site from thrombin $\left(R^{41}\right)$ and trigger an alternative signal cascade from thrombin [36]. In contrast, other proteases can disarm PARs to render them inactive to canonical proteases. A recent review by Hollenberg and colleagues eloquently summarized ligand-dependent biased signaling paradigms downstream of PAR activation [35]. Whilst reviews conventionally cover previously published literature, this review used a combination of previously published adapted data sets and unpublished examples to illustrate biased signaling via PARs. An example of PAR1 and PAR2 signaling bias was demonstrated using data sets comparing treatment with cockroach proteinase E1, neutrophil elastase (NE) and a biased PAR2 synthetic peptide, SLAAAA-NH ${ }_{2}$ respectively. These activators were shown to preferentially activate Ga12/13-MAP kinase pathways but not beta-arrestin or Gaq-calcium signaling cascades. Understanding the physiological relevance of these biased signaling pathways may help in effective regulation of PAR activity in the disease setting.

\section{PARs in disease - A focus on thrombosis}

One of the most researched areas of the PAR field is thrombin-mediated PAR activity in the cardiovascular system [18], in particular events downstream of PAR activation in platelets. Thrombin is pivotal in the regulation of hemostasis and thrombosis during vascular injury [37]. The cellular effects of thrombin in this context have largely been attributed to PARs expressed on platelets. In human platelets, PAR1 and PAR4 function as a 'dual receptor system' to promote platelet activation in response to changing levels of local thrombin generated at the sites of injury [38]. The formation of a PAR1/PAR4 heterodimer has since been proposed $[11,18]$ however the requirement of thrombin in promoting dimerization has been disputed. Early studies by Kuliopulos and colleagues demonstrated stable PAR1/PAR4 heterodimerization in recombinant 
cells systems which did not require thrombin cleavage [18]. Nieman and colleagues have since published a more detailed mechanism of PAR1/PAR4 dimer formation which details the essential role of thrombin cleavage in the promotion of heterodimerization [11]. In the latter investigation, heterodimer formation between PAR1 and PAR4 was only detected upon treatment with $\alpha$-thrombin (10nM, 10mins). The role of thrombin in this process was further demonstrated through inhibition of the exosite I of thrombin (where PAR1 binds). Under these conditions, PAR1 and PAR4 were unable to form heterodimers. Interestingly, PAR1 and PAR4 homodimerization was not influenced by thrombin.

Activation of PAR1 triggers fast, transient signaling cascades whereas PAR4, due to lack of receptor desensitization, evokes slow and sustained signaling responses [39]. The signaling pathways activated in response to thrombin via PAR1 in platelets include $\mathrm{G} \alpha \mathrm{q} / 11, \mathrm{G} \alpha 12 / 13$, and Gai/o, whilst PAR4 couples to $\mathrm{G} \alpha \mathrm{q} / 11$ and $\mathrm{G} \alpha 12 / 13$ but not Gai/o [40, 41]. Together these pathways promote platelet shape change, aggregation and secretion prior to thrombus formation. In the absence of PAR1 in mouse platelets, PAR4 forms a heterodimer with PAR3 to promote thrombin-mediated platelet activity [10]. PAR3 does not mediate signal transduction upon thrombin cleavage, instead its role in platelets is merely to act as a cofactor to enable PAR4 to transmit signals in response to thrombin [42]. The development of PAR1 antagonists to inhibit thrombin-mediated platelet function as an alternative antiplatelet strategy has been the most progressive to date.

\section{PARs as antiplatelet targets}

Following many years of development, the first PAR1 competitive antagonist, vorapaxar (Zontivity), was approved for clinical use in the United States as an adjunctive antiplatelet therapy in the treatment of acute coronary syndromes [43]. Incidentally, the widespread clinical use of this drug has been limited due to the severity of associated bleeding and increased risk of intracranial hemorrhage in patient cohorts with acute coronary syndromes (ACS) [43]. Further investigations are required to understand the major bleeding profile. These include studies to assess dosing issues, genomic/proteomic interplay or combination therapies given to the patients enrolled in the clinical trials (i.e. P2Y12 antagonist/aspirin). These factors may have contributed to the significant bleeding observed. The resolution of the PAR1-vorapaxar crystal structure has provided great insight into the vorapaxar binding site within PAR1 [15]. Unlike other GPCRs, which have deep binding pockets, vorapaxar binds with high affinity to the extracellular surface of PAR1 within a closed hydrophobic binding pocket. This closed binding mode explains the very slow dissociation rate $\left(t_{1 / 2}=\sim 3 \mathrm{hrs}\right)$ of vorapaxar [44]. When combined with the long elimination of vorapaxar ( $t_{1 / 2}=173-269$ hours) [45], this might be one explanation for the severe bleeding observed in patient cohorts. The development of PAR1 antagonists with faster dissociation and elimination rates may hold the key to improving patient bleeding profiles.

\section{Non-competitive modulators of PAR activity}

As an alternative to competitive inhibition of GPCRs, Kuliopulos, Covic and colleagues have designed a series of cell-penetrating lipidated peptide mimetics called pepducins that purportedly target intracellular loops (ICLs) of GPCRs [46]. The use of pepducins designed to mimic ICL1 and ICL3 regions of PAR1 and PAR2 has been successful in the allosteric regulation of $G$ protein signal transduction (Table 1). Through this approach, selective PAR1 and PAR2 agonist and antagonist pepducins have been generated [46]. Recent interrogation of the binding properties of the ICL3 PAR1 agonist pepducin, P1pal-19 revealed direct interaction with helix 8 (H8) of PAR1 [47]. In this study, activation of PAR1 by P1pal-19 involved the (D/N)PXXY motif in transmembrane-7 (TM7) and direct engagement with H8. Binding of P1pal-19, in turn, altered the positioning ofTM6 into an open 'on-state' conformation to enhance PAR1-G protein coupling. The specific binding properties of the other PAR pepducins have yet to be studied. However, the PAR1 pepducin antagonist PZ-128 (P1pal-7) is currently in clinical trials as a potential antiplatelet agent in the treatment of cardiovascular disease. Unlike vorapaxar, no adverse bleeding was reported when PZ-128 was tested 
in nonhuman primates [48]. Recent studies testing the clinical efficacy of PZ-128 in patients with vascular disease have now shown faster elimination rates with plasma levels of PZ-128 undetectable after 24 hours [49]. Whether this improves the bleeding severity and safety profile remains to be determined. Unfortunately pepducins designed to target PAR4 activity, namely P4pal-10, also partially inhibit PAR1 [46]. More selective PAR4 pepducins are currently in development.

The Flaumenhaft laboratory has also made progress in the development of small molecule PAR1 antagonists called parmodulins [50]. The parmodulin, ML-161, is a reversible allosteric PAR1 inhibitor that targets an intracellular region of the receptor. In this manner, ML-161 is able to selectively inhibit PAR1-Gaq/11 pathways whilst preserving Ga12/13 signaling in response to thrombin. Parmodulins have shown great promise in PAR1 platelet function however their potential as an alternative antiplatelet therapy of clinical value has yet to be ascertained.

\section{Targeting PAR4 as an alternative approach}

Strategies to inhibit PAR4 activity have been less successful than those directed towards targeting PAR1 and PAR2 activity. PAR4 is an important target as the inhibition of sustained platelet responses via thrombinPAR4 may offer another avenue to limit thrombin activity in the setting of thrombosis. The only non-peptide antagonist that exists for PAR4 is YD-3. This competitive PAR4 antagonist also weakly inhibits PAR1 activity in response to thrombin [51]. Furthermore, the actions of YD-3 may have limited use given recent data that showed platelets derived from patients harboring the rs773902 common variant (Ala120Thr) in the PAR4 gene (F2RL3) do not show PAR4 inhibition to YD-3 treatment [52]. PAR4-mediated platelet aggregation measured from washed platelets derived from homozygous rs773902 donors was not subject to the same level of pharmacological inhibition by YD-3 when compared with control donors. This PAR4 variant is more common in subjects of African ancestry therefore any future inhibitor derived from YD-3 may have limited use in this cohort of patients. Selectivity seems to be the key issue when attempting to target PAR4. Clearly more information regarding the regulatory mechanisms that underlie PAR4 activity is required if progress is to be made. PAR4 pharmacogenetic studies may reveal important structure-activity relationships that could help identify potentially targetable regions within PAR4, which in turn may aid the development of future PAR4 selective agents. Such studies may help identify an alternative inhibitory strategy to develop effective antagonists for patients harboring the PAR4 Ala120Thr common variant.

\section{Conclusions and Perspectives}

Dual antiplatelet therapies (aspirin and the P2Y12 receptor inhibitor Clopidogrel) are commonly prescribed to ACS patients to minimize cardiovascular events such as thrombosis however not all patients tolerate these drugs. Resistance to one or both of these drugs often results in recurrent thrombotic events. Failure of patients to respond to existing antiplatelet therapies is the reason why more drugs are being developed in this area. PARs are obvious targets due to their role in regulating thrombin-mediated platelet function. PAR-based treatments would offer an alternative way to inhibit platelet activation for those who do not respond to existing therapies. The therapeutic potential of PAR modulators developed to date have been explored following canonical activation of PARs, however their effectiveness against the emerging non-canonical proteases will be equally important in determining their widespread use. The mixed success of PAR1 competitive antagonists in the clinic has fueled development into alternative strategies to target PAR activity. Whilst the approaches that offer allosteric regulation of PAR activity seem like an attractive therapeutic option, their success will not be known until the outcome of ongoing clinical trials [49].

\section{Acknowledgements and Funding}

MRC is an independent Strathclyde Chancellor's Research Fellow funded by the University of 
Strathclyde and Tenovus Scotland [S15/09]. KMcl is a Senior Postdoctoral Research Fellow funded by Scottish Universities Life Science Alliance [MSDPD08] in the laboratory of RJP. GS is a PhD student in the laboratory of MC and is funded by a University of Strathclyde studentship. TB is a Senior Lecturer at the University of Strathclyde. 


\section{References}

1. Dery, O., Corvera, C.U., Steinhoff, M. and Bunnett, N.W. (1998) Proteinase-activated receptors: novel mechanisms of signaling by serine proteases. Am J Physiol. 274, C1429-52

2. Vu, T.K., Hung, D.T., Wheaton, V.I. and Coughlin, S.R. (1991) Molecular cloning of a functional thrombin receptor reveals a novel proteolytic mechanism of receptor activation. Cell. 64, 1057-68

3. Nystedt, S., Emilsson, K., Wahlestedt, C. and Sundelin, J. (1994) Molecular cloning of a potential proteinase activated receptor. Proc Natl Acad Sci U S A. 91, 9208-12

4. Xu, W.F., Andersen, H., Whitmore, T.E., Presnell, S.R., Yee, D.P., Ching, A., Gilbert, T., Davie, E.W. and Foster, D.C. (1998) Cloning and characterization of human protease-activated receptor 4. Proc Natl Acad Sci U S A. 95, 6642-6

5. Ishihara, H., Connolly, A.J., Zeng, D., Kahn, M.L., Zheng, Y.W., Timmons, C., Tram, T. and Coughlin, S.R. (1997) Protease-activated receptor 3 is a second thrombin receptor in humans. Nature. 386, 502-6

6. Zhao, P., Metcalf, M. and Bunnett, N.W. (2014) Biased signaling of protease-activated receptors. Front Endocrinol (Lausanne). 5, 67

7. Gallwitz, M., Enoksson, M., Thorpe, M. and Hellman, L. (2012) The extended cleavage specificity of human thrombin. PLoS One. 7, e31756

8. Nieman, M.T. and Schmaier, A.H. (2007) Interaction of thrombin with PAR1 and PAR4 at the thrombin cleavage site. Biochemistry. 46, 8603-10

9. Liu, L.W., Vu, T.K., Esmon, C.T. and Coughlin, S.R. (1991) The region of the thrombin receptor resembling hirudin binds to thrombin and alters enzyme specificity. J Biol Chem. 266, 16977-80

10. Nakanishi-Matsui, M., Zheng, Y.W., Sulciner, D.J., Weiss, E.J., Ludeman, M.J. and Coughlin, S.R. (2000) PAR3 is a cofactor for PAR4 activation by thrombin. Nature. 404, 609-13

11. Arachiche, A., Mumaw, M.M., de la Fuente, M. and Nieman, M.T. (2013) Protease-activated receptor 1 (PAR1) and PAR4 heterodimers are required for PAR1-enhanced cleavage of PAR4 by alpha-thrombin. J Biol Chem. 288, 32553-62

12. Bah, A., Chen, Z., Bush-Pelc, L.A., Mathews, F.S. and Di Cera, E. (2007) Crystal structures of murine thrombin in complex with the extracellular fragments of murine protease-activated receptors PAR3 and PAR4. Proc Natl Acad Sci U S A. 104, 11603-8

13. Lin, H., Liu, A.P., Smith, T.H. and Trejo, J. (2013) Cofactoring and dimerization of proteinaseactivated receptors. Pharmacol Rev. 65, 1198-213

14. Ishii, K., Gerszten, R., Zheng, Y.W., Welsh, J.B., Turck, C.W. and Coughlin, S.R. (1995) Determinants of thrombin receptor cleavage. Receptor domains involved, specificity, and role of the P3 aspartate. J Biol Chem. 270, 16435-40

15. Zhang, C., Srinivasan, Y., Arlow, D.H., Fung, J.J., Palmer, D., Zheng, Y., Green, H.F., Pandey, A., Dror, R.O., Shaw, D.E., Weis, W.I., Coughlin, S.R., and Kobilka, B.K. (2012) High-resolution crystal structure of human protease-activated receptor 1 . Nature. 492, 387-92

16. Ubl, J.J., Sergeeva, M. and Reiser, G. (2000) Desensitisation of protease-activated receptor-1 (PAR-1) in rat astrocytes: evidence for a novel mechanism for terminating $\mathrm{Ca} 2+$ signalling evoked by the tethered ligand. J Physiol. 525 Pt 2, 319-30

17. Hollenberg, M.D., Saifeddine, M., al-Ani, B. and Kawabata, A. (1997) Proteinase-activated receptors: structural requirements for activity, receptor cross-reactivity, and receptor selectivity of receptoractivating peptides. Can J Physiol Pharmacol. 75, 832-41

18. Leger, A.J., Covic, L. and Kuliopulos, A. (2006) Protease-activated receptors in cardiovascular diseases. Circulation. 114, 1070-7

19. Han, N., Jin, K., He, K., Cao, J. and Teng, L. (2011) Protease-activated receptors in cancer: A systematic review. Oncol Lett. 2, 599-608

20. McIntosh, K.A., Plevin, R., Ferrell, W.R. and Lockhart, J.C. (2007) The therapeutic potential of 
proteinase-activated receptors in arthritis. Curr Opin Pharmacol. 7, 334-8

21. Zania, P., Gourni, D., Aplin, A.C., Nicosia, R.F., Flordellis, C.S., Maragoudakis, M.E. and Tsopanoglou, N.E. (2009) Parstatin, the cleaved peptide on proteinase-activated receptor 1 activation, is a potent inhibitor of angiogenesis. J Pharmacol Exp Ther. 328, 378-89

22. Givvimani, S., Narayanan, N., Pushpakumar, S.B. and S, C.T. (2014) Anti-Parstatin Promotes Angiogenesis and Ameliorates Left Ventricular Dysfunction during Pressure Overload. Int J Biomed Sci. 10, 1-7

23. Diamantopoulos, A., Kyriazis, I., Geronatsiou, K., Papadaki, H., Loudos, G., Kagadis, G.C., Katsanos, K., Liatsikos, E., Karnabatidis, D., Siamblis, D., and Tsopanoglou, N.E. (2012) Parstatin prevents renal injury following ischemia/reperfusion and radiocontrast administration. Am J Nephrol. 36, 278-86

24. Gieseler, F., Ungefroren, H., Settmacher, U., Hollenberg, M.D. and Kaufmann, R. (2013) Proteinaseactivated receptors (PARs) - focus on receptor-receptor-interactions and their physiological and pathophysiological impact. Cell Commun Signal. 11, 86

25. Sriwai, W., Mahavadi, S., Al-Shboul, O., Grider, J.R. and Murthy, K.S. (2013) Distinctive G ProteinDependent Signaling by Protease-Activated Receptor 2 (PAR2) in Smooth Muscle: Feedback Inhibition of RhoA by cAMP-Independent PKA. PLoS One. 8, e66743

26. McCoy, K.L., Traynelis, S.F. and Hepler, J.R. (2010) PAR1 and PAR2 couple to overlapping and distinct sets of $\mathrm{G}$ proteins and linked signaling pathways to differentially regulate cell physiology. Mol Pharmacol. 77, 1005-15

27. Macfarlane, S.R., Seatter, M.J., Kanke, T., Hunter, G.D. and Plevin, R. (2001) Proteinase-activated receptors. Pharmacol Rev. 53, 245-82

28. McLaughlin, J.N., Patterson, M.M. and Malik, A.B. (2007) Protease-activated receptor-3 (PAR3) regulates PAR1 signaling by receptor dimerization. Proc Natl Acad Sci U S A. 104, 5662-7

29. Ostrowska, E. and Reiser, G. (2008) The protease-activated receptor-3 (PAR-3) can signal autonomously to induce interleukin-8 release. Cell Mol Life Sci. 65, 970-81

30. Seminario-Vidal, L., Kreda, S., Jones, L., O'Neal, W., Trejo, J., Boucher, R.C. and Lazarowski, E.R. (2009) Thrombin promotes release of ATP from lung epithelial cells through coordinated activation of rho- and Ca2+-dependent signaling pathways. J Biol Chem. 284, 20638-48

31. Faruqi, T.R., Weiss, E.J., Shapiro, M.J., Huang, W. and Coughlin, S.R. (2000) Structure-function analysis of protease-activated receptor 4 tethered ligand peptides. Determinants of specificity and utility in assays of receptor function. J Biol Chem. 275, 19728-34

32. Holinstat, M., Voss, B., Bilodeau, M.L., McLaughlin, J.N., Cleator, J. and Hamm, H.E. (2006) PAR4, but not PAR1, signals human platelet aggregation via Ca2+ mobilization and synergistic P2Y12 receptor activation. J Biol Chem. 281, 26665-74

33. Li, D., D'Angelo, L., Chavez, M. and Woulfe, D.S. (2011) Arrestin-2 differentially regulates PAR4 and ADP receptor signaling in platelets. J Biol Chem. 286, 3805-14

34. Darmoul, D., Gratio, V., Devaud, H., Peiretti, F. and Laburthe, M. (2004) Activation of proteinaseactivated receptor 1 promotes human colon cancer cell proliferation through epidermal growth factor receptor transactivation. Mol Cancer Res. 2, 514-22

35. Hollenberg, M.D., Mihara, K., Polley, D., Suen, J.Y., Han, A., Fairlie, D.P. and Ramachandran, R. (2014) Biased signalling and proteinase-activated receptors (PARs): targeting inflammatory disease. $\mathrm{Br} \mathrm{J}$ Pharmacol. 171, 1180-94

36. Mosnier, L.O., Sinha, R.K., Burnier, L., Bouwens, E.A. and Griffin, J.H. (2012) Biased agonism of protease-activated receptor 1 by activated protein $C$ caused by noncanonical cleavage at Arg46. Blood. 120, 5237-46

37. Crawley, J.T., Zanardelli, S., Chion, C.K. and Lane, D.A. (2007) The central role of thrombin in hemostasis. J Thromb Haemost. 5 Suppl 1, 95-101

38. Kahn, M.L., Zheng, Y.W., Huang, W., Bigornia, V., Zeng, D., Moff, S., Farese, R.V., Jr., Tam, C. and Coughlin, S.R. (1998) A dual thrombin receptor system for platelet activation. Nature. 394, 690-4 
39. Shapiro, M.J., Weiss, E.J., Faruqi, T.R. and Coughlin, S.R. (2000) Protease-activated receptors 1 and 4 are shut off with distinct kinetics after activation by thrombin. J Biol Chem. 275, 25216-21

40. Voss, B., McLaughlin, J.N., Holinstat, M., Zent, R. and Hamm, H.E. (2007) PAR1, but not PAR4, activates human platelets through a Gi/o/phosphoinositide-3 kinase signaling axis. Mol Pharmacol. 71, 1399-406

41. Offermanns, S. (2006) Activation of platelet function through G protein-coupled receptors. Circ Res. 99, 1293-304

42. Weiss, E.J., Hamilton, J.R., Lease, K.E. and Coughlin, S.R. (2002) Protection against thrombosis in mice lacking PAR3. Blood. 100, 3240-4

43. Tricoci, P., Huang, Z., Held, C., Moliterno, D.J., Armstrong, P.W., Van de Werf, F., White, H.D., Aylward, P.E., Wallentin, L., Chen, E., Lokhnygina, Y., Pei, J., Leonardi, S., Rorick, T.L., Kilian, A.M., Jennings, L.H., Ambrosio, G., Bode, C., Cequier, A., Cornel, J.H., et al. (2012) Thrombin-receptor antagonist vorapaxar in acute coronary syndromes. N Engl J Med. 366, 20-33

44. Hawes, B.E., Zhai, Y., Hesk, D., Wirth, M., Wei, H., Chintala, M. and Seiffert, D. (2015) In vitro pharmacological characterization of vorapaxar, a novel platelet thrombin receptor antagonist. Eur J Pharmacol. 762, 221-8

45. Kosoglou, T., Reyderman, L., Tiessen, R.G., van Vliet, A.A., Fales, R.R., Keller, R., Yang, B. and Cutler, D.L. (2012) Pharmacodynamics and pharmacokinetics of the novel PAR-1 antagonist vorapaxar (formerly SCH 530348) in healthy subjects. Eur J Clin Pharmacol. 68, 249-58

46. O'Callaghan, K., Kuliopulos, A. and Covic, L. (2012) Turning receptors on and off with intracellular pepducins: new insights into G-protein-coupled receptor drug development. J Biol Chem. 287, 12787-96

47. Zhang, P., Leger, A.J., Baleja, J.D., Rana, R., Corlin, T., Nguyen, N., Koukos, G., Bohm, A., Covic, L. and Kuliopulos, A. (2015) Allosteric Activation of a G Protein-coupled Receptor with Cell-penetrating Receptor Mimetics. J Biol Chem. 290, 15785-98

48. Zhang, P., Gruber, A., Kasuda, S., Kimmelstiel, C., O'Callaghan, K., Cox, D.H., Bohm, A., Baleja, J.D., Covic, L. and Kuliopulos, A. (2012) Suppression of arterial thrombosis without affecting hemostatic parameters with a cell-penetrating PAR1 pepducin. Circulation. 126, 83-91

49. Gurbel, P.A., Bliden, K.P., Turner, S.E., Tantry, U.S., Gesheff, M.G., Barr, T.P., Covic, L. and Kuliopulos, A. (2016) Cell-Penetrating Pepducin Therapy Targeting PAR1 in Subjects With Coronary Artery Disease. Arterioscler Thromb Vasc Biol. 36, 189-97

50. Aisiku, O., Peters, C.G., De Ceunynck, K., Ghosh, C.C., Dilks, J.R., Fustolo-Gunnink, S.F., Huang, M., Dockendorff, C., Parikh, S.M. and Flaumenhaft, R. (2015) Parmodulins inhibit thrombus formation without inducing endothelial injury caused by vorapaxar. Blood. 125, 1976-85

51. Young, S.E., Duvernay, M.T., Schulte, M.L., Lindsley, C.W. and Hamm, H.E. (2013) Synthesis of indole derived protease-activated receptor 4 antagonists and characterization in human platelets. PLoS One. 8, e65528

52. Edelstein, L.C., Simon, L.M., Lindsay, C.R., Kong, X., Teruel-Montoya, R., Tourdot, B.E., Chen, E.S., Ma, L., Coughlin, S., Nieman, M., Holinstat, M., Shaw, C.A., and Bray, P.F. (2014) Common variants in the human platelet PAR4 thrombin receptor alter platelet function and differ by race. Blood. 124, 3450-8 
Figures and Tables:

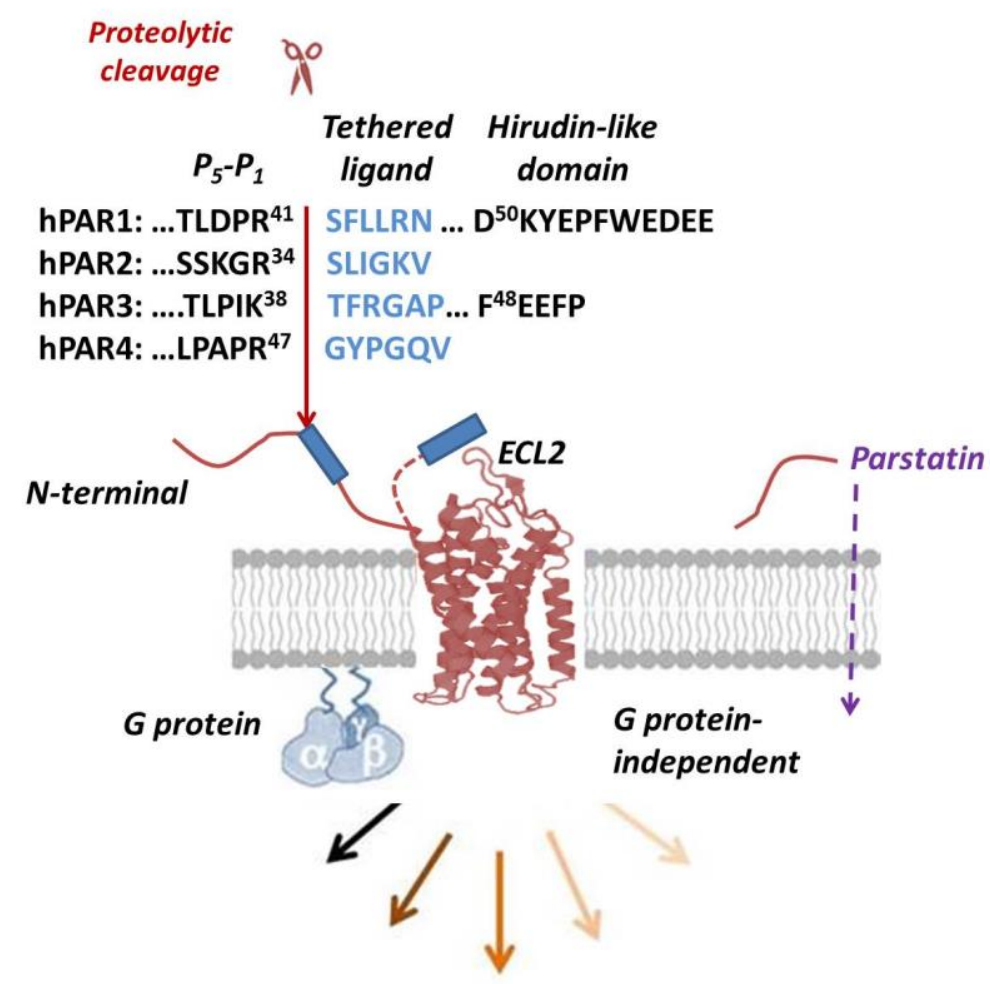

PAR Roles:

Cardiovascular disease

Inflammation

Cancer

Neuroregulation
Signal transduction

\section{Figure 1: Canonical cleavage of PARs}

Serine proteases such as thrombin or trypsin recognize and cleave PARs distinct residues that reside within the extracellular $\mathrm{N}$-terminus. The hirudin-like domain within PAR1 and PAR3 facilitate the recognition and thrombin-binding process. Proteolytic cleavage results in the liberation of part of the $\mathrm{N}$-terminus to reveal a tethered ligand domain. This tethered ligand region promotes 'self-activation' of PARs through superficial engagement with distinct residues that comprise the extracellular loop 2 (ECL2) domain. Upon receptor activation, $G$ protein and $G$ protein-independent pathways are stimulated. The signal transduction cascades that emanate from PARs following canonical activation have been characterized in the context of cardiovascular disease, inflammation and cancer. PAR-independent roles for the liberated peptide, 'parstatin', have also emerged.

Table 1: Known agonists and antagonists of the PAR family 


\begin{tabular}{|c|c|c|c|c|}
\hline & PAR1 & PAR2 & PAR3 & PAR4 \\
\hline Gene Name & $F 2 R$ & F2RL1 & F2RL2 & F2RL3 \\
\hline $\begin{array}{l}\text { G protein } \\
\text { transduction }\end{array}$ & $G \alpha_{q / 11}, G \alpha_{i / o}, G \alpha_{12 / 13}$ & $G \alpha_{q / 11}, G \alpha_{i / 0}, G \alpha_{12 / 13}$ & non-signaling receptor & $G \alpha_{q / 11}, G \alpha_{i / o}$ \\
\hline $\begin{array}{l}\text { Agonist } \\
\text { proteases }\end{array}$ & $\begin{array}{l}\text { Thrombin } \\
\text { Factor Xa } \\
\text { Plasmin } \\
\text { Activated protein C } \\
\text { (APC) } \\
\text { Matrix } \\
\text { metalloproteinases } \\
\text { (MMPs) - MMP1 and } \\
\text { MMP13 } \\
\text { Elastase } \\
\text { Proteinase } 3 \\
\text { Granzyme K } \\
\text { Kallikreins (KLKs) -KLK4 }\end{array}$ & $\begin{array}{l}\text { Trypsin } \\
\text { Tryptase } \\
\text { Factor VIla } \\
\text { Factor Xa (FXa) } \\
\text { KLK2, KLK4, KLK14 } \\
\text { Neutrophil elastase } \\
\text { Cathepsin S } \\
\text { Gingipain } \\
\text { Testisin } \\
\text { Matriptase }\end{array}$ & $\begin{array}{l}\text { Thrombin } \\
\text { APC } \\
\text { FXa }\end{array}$ & $\begin{array}{l}\text { Thrombin } \\
\text { Trypsin } \\
\text { Plasmin } \\
\text { Cathepsin G } \\
\text { MASP1 } \\
\text { KLK14 }\end{array}$ \\
\hline $\begin{array}{l}\text { Disarming } \\
\text { proteases }\end{array}$ & $\begin{array}{l}\text { Trypsin (at low } \\
\text { concentrations) } \\
\text { Cathepsin G } \\
\text { Chymotrypsin } \\
\text { Kallikreins (KLKs) - KLK14 } \\
\text { Implantation serine } \\
\text { proteinase 2 (ISP2) } \\
\end{array}$ & $\begin{array}{l}\text { Neutrophil elastase } \\
\text { Cathepsin G } \\
\text { Proteinase } 3 \\
\text { Elastolytic } \\
\text { metalloproteinase (EPa) } \\
\text { ISP2 }\end{array}$ & $\begin{array}{l}\text { Neutrophil elastase } \\
\text { Cathepsin G }\end{array}$ & ISP2 \\
\hline $\begin{array}{l}\text { Selective } \\
\text { agonists }\end{array}$ & TFLLR-NH & $\begin{array}{l}\text { SLIGKV-NH }{ }_{2}, \mathrm{SLIGRL-NH}{ }_{2}, \\
\text { SLAAAA-NH }{ }_{2}{ }^{\Delta} \\
\text { 2-furoyl-LIGRLO-amide } \\
\text { GB } 110\end{array}$ & APC mimetics - P3 $R_{M}, P 3 R_{L}$ & $\begin{array}{l}\text { GYPGKF-NH } \\
\text { AYPGKF-NH } \\
\text { AYPGKV-NH } \\
\text { AYPGQV-NH } \\
\text { AYPGQ }\end{array}$ \\
\hline $\begin{array}{l}\text { Selective } \\
\text { antagonists }\end{array}$ & $\begin{array}{l}\text { SCH-530348 (Vorapaxar), } \\
\text { SCH-79797 } \\
\text { E5555 (Atopaxar, in } \\
\text { clinical trials) } \\
\text { RWJ-56110 } \\
\text { ER-129614-06 } \\
\text { BMS-200261 } \\
\text { ML161 - Parmodulin2 } \\
\text { (allosteric) } \\
\text { Q94 hydrochloride } \\
\text { (allosteric) }\end{array}$ & $\begin{array}{l}\text { GB83, GB88* } \\
\text { ENMD-1068 } \\
\text { K14585 }\end{array}$ & & $\begin{array}{l}\text { tc-YGPKF } \\
\text { YD-3 }\end{array}$ \\
\hline $\begin{array}{l}\text { Pepducin } \\
\text { Agonists }\end{array}$ & $\begin{array}{l}\text { P1pal-19 } \\
\text { P1pal-13 }\end{array}$ & $\begin{array}{l}\text { P2pal-21 (partial) } \\
\text { P2pal-21F (also activates } \\
\text { PAR1) }\end{array}$ & & \\
\hline $\begin{array}{l}\text { Pepducin } \\
\text { Antagonists }\end{array}$ & $\begin{array}{l}\text { P1pal-12, P2pal-12S, } \\
\text { P4pal-10 (partial) } \\
\text { PZ-128 (P1pal-7, in } \\
\text { clinical trials) }\end{array}$ & $\begin{array}{l}\text { P2pal-18s**, } \\
\text { P2pal-14GQ }\end{array}$ & & $\begin{array}{l}\text { P4pal-i1, } \\
\text { P4pal-10*** }\end{array}$ \\
\hline $\begin{array}{l}\text { Clinically used } \\
\text { antagonists }\end{array}$ & Vorapaxar & & & \\
\hline
\end{tabular}

Table 1: Known agonists and antagonists of the PAR family

*Biased PAR2 partial-agonist-antagonist, ** biased antagonist [22], *** selectivity issues - partial inhibition of PAR1 activity, ${ }^{\Delta}$ biased PAR2 agonist 
